Article

\title{
A Critical Survey of Environmental Content in United States Undergraduate Mechanical Engineering Curricula
}

\author{
Charles E. Sprouse III *D, Maximilian Davy ${ }^{D}$, Anna Doyle and Grace Rembold
}

check for

updates

Citation: Sprouse, C.E. III; Davy, M.; Doyle, A.; Rembold, G. A Critical Survey of Environmental Content in United States Undergraduate Mechanical Engineering Curricula. Sustainability 2021, 13, 6961. https:// doi.org/10.3390/su13126961

Academic Editors: Dina Mateus,

Alexandros Stefanakis and

Henrique Pinho

Received: 3 May 2021

Accepted: 11 June 2021

Published: 21 June 2021

Publisher's Note: MDPI stays neutral with regard to jurisdictional claims in published maps and institutional affiliations.

Copyright: (c) 2021 by the authors. Licensee MDPI, Basel, Switzerland. This article is an open access article distributed under the terms and conditions of the Creative Commons Attribution (CC BY) license (https:// creativecommons.org/licenses/by/ $4.0 /)$.
School of Engineering, Benedictine College, Atchison, KS 66002, USA; davy3885@ravens.benedictine.edu (M.D.); doy12090@ravens.benedictine.edu (A.D.); remb6238@ravens.benedictine.edu (G.R.)

* Correspondence: csprouse@benedictine.edu; Tel.: +1-913-360-7958

Abstract: This survey examines how mechanical engineers are being prepared to be responsible stewards of the environment by offering a multi-channeled look at a diverse collection of twelve US colleges and universities, with connections to the larger global context. This study enumerates the external influences of professional organizations, those responsible for program accreditation (Accreditation Board for Engineering and Technology (ABET)), professional conduct (American Society of Mechanical Engineers), and licensure (National Council of Examiners for Engineering and Surveying, National Society of Professional Engineers). At the curricular level, this study presents current mechanical engineering curricula via core courses (required at most institutions) and non-core courses (required at a minority of institutions or elective courses). The curriculum study identifies fifteen core courses and uses the Open Syllabus Project and online bookstores to identify a representative textbook and classify the environmental content therein. Immediate results show the environment receiving sparse treatment in core course textbooks, institutions having zero environment-focused degree requirements, and a tendency towards offering electives that are narrowly focused on green technologies. Elective offerings mirror ABET's recent move away from emphasizing the "broad education necessary to understand the impact" of engineering solutions to instead "consider the impact of" engineering solutions in an environmental context. Overall, the environmental education mechanical engineers are receiving is insufficient in amount and lacking in scientific and ethical foundation. Ideally, every mechanical engineering program should include coordinated environmental content throughout the curriculum and require at least one course that teaches both environmental design principles and the importance of environmental stewardship. A novel approach eschews the typical artes mechanicae course structure to teach environmental stewardship in the artes liberales educational tradition, emphasizing multi-dimensional thinking by employing great books style discussions of seminal scientific, ethical, and technological works.

Keywords: mechanical engineering curricula; environmental stewardship; integral ecology; green engineering

\section{Introduction}

Engineering is known as a profession that serves an important role in society, uniquely equipped to apply scientific knowledge to develop technologies for the betterment of humankind. Unfortunately, this common refrain disregards the responsibility of engineers towards the planet, which has intrinsic value. As the broadest engineering discipline, mechanical engineering (ME) makes especially vast impacts on the environment and society. Engineers fulfill their vocation by recognizing that one thing that every human being has in common is the planet we all share. Because of this commonality, all people are affected by ocean acidification, deforestation, and atmospheric pollution. Mitigating these environmental impacts involves appreciating nature's interconnected "web" of complex relationships, further reinforcing the need for engineers dedicated to ecological integrity.

Engineers today have an unprecedented capacity to rapidly develop tools which make life easier for humanity yet make it harder for nature to maintain itself. The environment 
can readily be exploited for its many resources in energy and raw materials, offering many benefits to the human race, yet doing so represents an abdication of engineers' responsibility. Moving forward, engineers "can be thought of as non-elected representatives of the public, representatives who help 'legislate' concerning technology" (p. 126, [1]). Engineering should acknowledge its role in the rise of consumerism and its devastating effects on our planet, as well as the technocratic paradigm further dividing the poor from the rich.

\subsection{Research Question}

Up until this work, there have not been any aggregated or detailed studies on the environmental content in ME programs. Without any concrete data, academicians are left speculating about the state of environmental education, which stunts environmental discourse within the discipline. Thus, the fundamental question at hand in the present work is how US undergraduate mechanical engineering programs are preparing students to care for the environment.

Ultimately, by offering information on the environmental education that is occurring on a curriculum-wide basis, this study aims to initiate a global discussion on the environmental education that should be occurring. As such, detailed information on degree requirements and course content across curricula answers the research question and commences a discussion on the merits of various organizational structures in pursuit of efficacious sustainability education.

\subsection{Unified Global Dialogue}

As an educational practice, merely interspersing basic information on recyclability and alternative energy sources fails to convey the richness and complexity of our natural world; thus, an attractive avenue for preparing engineers to be faithful stewards of the environment is through interdisciplinary collaboration, including taking an intellectually honest look at the wisdom of other academic disciplines. For example, Pope Francis, leader of the world's Catholics and widely respected religious figure, dedicated his second encyclical to the environment, titled Laudato Si' [2]. Aiming to foster dialogue, the pontiff addressed Laudato $i^{\prime}$ to "all people" of the world (p. 8, [2]). The document is written for a diverse global audience and makes a strong moral case for broad and swift environmental action. While not all engineers are Christian, or even religious, the prudence of taking environmental issues into consideration while making decisions is apparent based on natural law, current societal laws and expectations, and the ethical duties of the engineering profession.

\subsection{Linguistic Influences on Ecological Mindset}

Undertaking a multi-disciplinary effort (e.g., involving technologists, scientists, and all inhabitants) to address a major global challenge requires effective communication, beginning with suitable language, words, and definitions. Within the US, "green" is easily grasped as environmentally beneficial, as is "eco-friendly"; however, what these words offer in terms of common understanding, at the same time, inhibits their ability to find use in serious academic pursuits. "Sustainability" conveys a distinct mode of environmentally conscious thought important to engineering, namely, considering the question, "could this practice continue on through future generations?" The term sustainability, however, has increasingly become adopted in the calculus of social and economic engineering efforts, built upon the idea that sound engineering work should be sustainable economically, socially, and environmentally [3]. This "triple bottom line" approach is constructive in ensuring social and environmental factors are not neglected in deference to economic factors, yet there are flaws inherent to this structure that motivate educators to seek qualitative language.

For an all-encompassing view, engineering should embrace an "integral ecology", wherein societal and environmental issues are regarded as highly important issues in a strongly interconnected world, and economic concerns are assigned lower priority. The key distinctions between the two approaches are: 
1. An integral ecology considers all elements together, recognizing their interconnectedness, as opposed to considering them separately.

2. The triple bottom line approach is an expansion of economic calculus to social and environmental issues, areas not governed by calculations. Nature is not a problem to be solved via calculation since the overall outcome does not equal the sum of individual factors.

"Integral ecology" offers an appropriate vision for engineering work, and its natural companion in personal terms is "environmental stewardship". This term disposes engineers in the proper way for approaching environmental questions; when engineers consider themselves stewards of the environment, they are caring for something entrusted to their care. By contrast, sustainability language more naturally suits the faulty mindset of not squandering that which engineers and society have available and ignores the possibility of actions being sustainable while also being unethical or being sustainable when they could be restorative. In other words, many sustainable practices are unethical (e.g., needlessly harming a rapidly reproducing species) or merely sustainable (e.g., rich companies/countries targeting "carbon neutral" instead of "carbon negative").

\section{Materials and Methods}

Structurally, this study uses the 2006 work of Glavič as its baseline methodology, which examined the environmental content of "environmental science and engineering programs" in Europe and the United States, with a focus on "chemical engineering and applied chemistry departments" (p. 24, [4]). While not an exact correlation, this study shares the objective of characterizing the environmental content in programs within an engineering discipline, with this study considering mechanical and Glavič considering chemical. Glavič captured and characterized institutional offerings by casting a very wide net, lumping together required courses and electives, undergraduate and graduate courses, and engineering, science, and technological courses in the pursuit of a "multidisciplinary approach" (p. 26, [4]). By contrast, the present study strictly considers courses that fulfill undergraduate mechanical engineering degree requirements, and preserves the difference between required and elective courses, since electives are subject to student choice. In that way, the present methodology is focused on the environmental education students receive, rather than the environmental offerings institution wide.

\subsection{Overview of Methodology of Curriculum-Wide Survey}

To fully capture the instruction mechanical engineers receive on environmental topics on a curriculum-wide basis, this study takes a deliberate, holistic approach. Three main drivers of environmental education receive thorough treatment: influences of external organizations, environmental content in core courses (common program requirements), and environmental content in non-core courses (uncommon program requirements, elective offerings).

Examining the influences of external organizations is essential for contextualizing curricula, since academicians aim to meet the requirements of bodies governing accreditation, professional conduct, and licensure. Thus, the present study examines longitudinal changes in Accreditation Board for Engineering and Technology (ABET) program accreditation criteria, elucidates the professional conduct expectations of the American Society of Mechanical Engineers (ASME), and enumerates the licensure requirements of the National Council of Engineers for Engineering and Surveying (NCEES) and National Society of Professional Engineers (NSPE). As the only global accreditor of baccalaureate engineering programs, ABET's criteria are relevant to programs worldwide. Regarding professional societies, those in the United States tend to be more active than their counterparts across the world, whereas non-US programs tend to encounter additional governmental influences. Government regulations may be highly consequential, due to the potential for withholding public funding and loan guarantees. Determining the environmental content common across programs (in core courses) and unique to certain programs (in non-core courses) 
captures the baseline sustainability education received by today's graduates and highlights the additional educational opportunities available at specific institutions. Performing the curricular study is an exceptionally intensive process. A group of undergraduate ME programs is selected, each of which is studied thoroughly to allow for the characterization of the environmental content therein. Upon identifying the degree requirements for each program, each course that satisfies a degree requirement (as a required course or elective course) is examined for environmental content using the catalog course description, syllabus, and required textbook(s). With an average degree program having approximately 30 required courses and offering 20-50 elective courses, the amount of information gathered is voluminous. Meaningful analysis occurs through program comparisons, revealing a set of "core" courses taken by most ME undergraduates as well as "non-core" courses that vary institution by institution. Differences in approach to environmental education are also included as results, including variations in textbook organization, course structure, and curricular integration.

\subsection{Selection of Programs for Survey}

The institutions included in the curricular study begin with the top ten undergraduate mechanical engineering programs for 2021, according to the US News and World Report [5]. The organization selected the ten schools from the "213 engineering schools that grant doctoral degrees" [6]. For the final two schools, the study aimed to complement the larger, more technologically focused programs, with smaller programs featuring strong liberal arts and faith-based requirements. Since only two institutions have independent ABET accreditation for their undergraduate mechanical engineering program and endorsement by the Cardinal Newman Society in The Newman Guide to Choosing a Catholic College [7], those became the eleventh and twelfth institutions in the study:

1. Massachusetts Institute of Technology [MIT] [8]

2. Georgia Institute of Technology [Georgia Tech] [9]

3. Stanford University [Stanford] [10]

4. University of Michigan, Ann Arbor [Michigan] [11]

5. University of California-Berkeley [UC Berkeley] [12]

6. California Institute of Technology [Caltech] [13]

7. Purdue University-West Lafayette [Purdue] [14]

8. University of Illinois-Urbana-Champaign [Illinois] [15]

9. Carnegie Mellon University [Carnegie Mellon] [16]

10. University of Texas at Austin [Texas] [17]

11. Benedictine College [BC] [18]

12. Catholic University of America [CUA] [19]

These twelve US-based programs include funding structures public and private, sizes large and small, locations coastal and inland, curricula technical and liberal arts, and worldviews secular and religious. While the foundational subject matter of mechanical engineering programs is expected to correlate across institutions, highly ranked and unique programs were chosen due to their potential for being leading adopters of exemplary curricular changes.

\subsection{Core and Non-Core Courses}

"Core" courses are explicit degree requirements for most programs. Since these courses center on engineering fundamentals, their contributions to environmental education are established based on the environmental content in popular core course textbooks, identified through the Open Syllabus Project [20] and institutional bookstores. As such, these courses are described course by course, with the environmental content contained therein being classified according to amount and textual integration.

"Non-core" environmentally focused courses fall into two categories, explicitly required courses and courses that satisfy elective requirements. As a direct consequence of being non-core, these courses vary across programs, and are best described institution by 
institution. By describing the unique environmentally focused offerings of each program, the survey recognizes differences in course structure and subject matter. For example, some courses tend to be predominantly focused on green technologies like wind energy, while others center on more fundamental topics like principles of sustainability or low impact development.

\subsection{Historical Context}

Glavič's 2006 study found more uniformity among US programs than those of Europe, perhaps due to the external influence of the Accreditation Board of Engineering and Technology (ABET), which is elucidated by Splitt [21], Shuman et al. [22], and Bucciarelli et al. [23]. (ABET accreditation remains relatively rare in Europe, but not in areas like South America, the Middle East, Australia, India, and China. Today, one-third of the programs ABET accredits are outside the US, with over 800 visits per annum.) Among seven subject groups common for sustainability courses, the most common group was green manufacturing. Concomitant results included the general finding that chemical engineering programs tended to include environmental electives but did not have environmentally focused degree requirements, and the author listed the six "most frequently employed textbooks" for environmental engineering, most of which covered either "the engineering approach" or "environmental sciences" (p. 29, [4]). If mechanical engineering mirrors chemical engineering, programs will have eco-centric electives yet no eco-centric degree requirements. Civil engineering programs, by contrast, typically have "environmental engineering" degree requirements (often specifically geared towards water quality and hazardous wastes).

Numerous studies by civil and environmental engineers inform the critiques offered by the present work. Wareham and Elefsiniotis detailed the necessity of environmental ethics in engineering curricula, including instruction on pollution prevention and remediation [24]. Hyde et al. detailed an innovative hydrology course design providing "information about how hydrological phenomena affect fish", including empathy-focused assignments using a narrative format [25] (p. 383). The next year Hyde and Karney demonstrated the importance and challenges of "knowing" versus "caring" (about environmental issues) [26] (p. 267). A decade later, Lathem et al. [27] illustrated how environmental stewardship fits under the umbrella of social responsibility, and Roeser [28] explained how caring for the environment demonstrates emotional health.

Modern scholarship explores a range of program-level educational strategies, including curricular structures and environmental language. This research landscape includes a description of a unique curriculum-wide coordinated structure for teaching sustainability using project-based learning [29], a sequence of e-learning activities [30], and the widespread use of guided discovery instruction [31]. Language wise, the evolution of environmental language includes the emergence of "overconsumption" [1] (p. 124), "sustainable development" [32] (p. 297), "sustainable design" [33] (p. 252), and "life cycle assessment" [34] (p. 154). A relevant work on environmental terminology, skewed towards chemical engineering, was authored by Glavič and Lukman [35]. Going forward with the baseline information provided by this survey, the research community would benefit from detailed descriptions of new curricula featuring coordinated environmental instruction across entire programs, with pre- and post-test results on attitudes and competencies (a single course module example is [34]).

\section{Results}

Organizationally, the first results subsection (Section 3.1) presents the influences of various external organizations on the environmental content in ME programs, after which the curricular study of Section 3.2 synthesizes information from the 12 curricula surveyed to present the environmental content in core and non-core courses, highlighting the amount of sustainability education in core course textbooks and the subject matter in eco-focused 
electives. After presenting results on individual drivers of environmental education, the final subsection (Section 3.3) critically analyzes the survey results holistically.

\subsection{Influences of External Organizations}

For mechanical engineering programs in the United States, achieving ABET accreditation is a valuable, almost indispensable, step in demonstrating and maintaining program quality. ABET has a set of seven student outcomes (SOs 1-7) for which programs must provide evidence of student achievement by the time of graduation, including outcomes related to the environment [36]. Three of ABET's member societies are ASME, NSPE, and NCEES [37], each having their own independent influences on baccalaureate mechanical engineering programs.

ASME is the largest professional society for mechanical engineers in practice, and they publish the "Code of Ethics of Engineers" [38] (p. 1), which contains environmental content that is likely to appear in course modules on ethics. The NSPE publishes a "Code of Ethics for Engineers" containing similar language [39] (p. 1), and failure to abide by the Code could prevent graduates from achieving or maintaining licensure as Professional Engineers (PEs). Similarly, the environmental content in NCEES' Fundamentals of Engineering (FE) exam is relevant as programs aim to have graduates become Engineers in Training (EIT), a precondition for eventually becoming a PE.

\subsubsection{Accreditation Board of Engineering and Technology (ABET)}

ABET sets baseline standards for baccalaureate programs, and according to their website, "ABET accreditation assures confidence that a collegiate program has met standards essential to prepare graduates to enter critical STEM fields in the global workforce" [40]. While ABET's standards deal with administrative and assessment practices, the organization places primary importance on student achievement and improvement on the organization's student outcomes [36]. ABET publishes accreditation criteria each academic year, sometimes without change, such as between 2019-2020 and 2020-2021, and other times, like between 2018-2019 and 2019-2020, significant changes occur [41,42]. For 20192020 , the previous year's student outcomes were condensed and restructured from (a)-(k) to (1)-(7). The environment is mentioned in two student outcomes in each set, as shown in Table 1, yet the accompanying language includes several changes, and each change in language has an influence on engineering curricula.

Table 1. Comparison of ABET student outcomes between academic year 2018-2019 and 2019-2020 [41,42].

2018-2019 ABET Student Outcome

(c) an ability to design a system, component, or process to meet desired needs within realistic constraints such as economic, environmental, social, political, ethical, health and safety, manufacturability, and sustainability

(h) the broad education necessary to understand the impact of engineering solutions in a global, economic, environmental, and societal context
2019-2020 ABET Student Outcome

(2) an ability to apply engineering design to produce solutions that meet specified needs with consideration of public health, safety, and welfare, as well as global, cultural, social, environmental, and economic factors

(4) an ability to recognize ethical and professional responsibilities in engineering situations and make informed judgments, which must consider the impact of engineering solutions in global, economic, environmental, and societal contexts

Comparing the new to the old, outcome (2) is similar to (c), with a subtle but important difference moving from environmental "constraints" to "consideration of" the environment. While "consideration of" is relatively weak and subjective language, ABET commendably places the environment in a position of value worth considering, instead of a constraint that may be viewed as an obstacle. Optimistically, the change could cause more programs to provide instruction on carefully considering the environment as part of "applying engineering design", as opposed to meeting a few environment-related constraints on a requirements list. 
Outcome (4) represents a structural change from (h) by placing environmental issues squarely in the realm of ethics and marrying (h) to (f), the old criteria's outcome focused on ethics. With environmental impact tied to ethics, more programs can now drive at the question "is this environmental impact moral?" instead of merely "understanding" environmental impact. The drawback, though, is the abandonment of the pedagogical concept of providing a "broad education", potentially furthering the trend of engineering programs moving away from the artes liberales (liberal arts) to concentrate on the artes mechanicae (mechanical arts). A danger, then, is programs asking the right questions without equipping students to properly answer them. Moreover, the environment continues to be evaluated as one consideration among many ("global, economic, environmental, and societal"), obscuring direct measurements of student achievement on environmental topics. Finally, demonstrating "consideration" demands little in terms of environmental knowledge and sensitivity.

\subsubsection{American Society of Mechanical Engineers (ASME)}

Fundamental Canon \#8 in the ASME Code of Ethics of Engineers states, "Engineers shall consider environmental impact and sustainable development in the performance of their professional duties" [38] (p. 2), which is sufficiently non-specific to merit subsequent interpretation guidance, especially since "consider" is a procedural term that may be difficult to characterize. In ASME's document titled The ASME Criteria for Interpretation of the Canons, also published in 2012, the society offers three points of guidance on interpretation for Canon 8, lettered (a)-(c) [43] (p. 8):

a. Engineers shall concern themselves with the impact of their plans and designs on the environment. When the impact is a clear threat to health or safety of the public, then the guidelines for this Canon revert to those of Canon 1. (emphasis added)

b. "Sustainable development" is the challenge of meeting human needs for natural resources, industrial products, energy, food, transportation, shelter, and effective waste management while conserving and protecting environmental quality and the natural resource base essential for future development.

Essentially, a and b prioritize human safety and health when trade-offs exist between humanity and the rest of the environment, while guidance point c provides a thorough definition for the phrase "sustainable development" in Canon 8, clarifying its scope to include meeting fundamental human needs (food, shelter, etc.) and "conserving and protecting environmental quality ... for future development". Altogether, ASME's influence on programs through Canon 8 supports giving the environment "consideration" during design, and most of its interpretive guidance advocates for deferring to human health and safety in the presence of trade-offs.

\subsubsection{National Society of Professional Engineers (NSPE)}

The NSPE Code of Ethics for Engineers states that "engineers are encouraged to adhere to the principles of sustainable development in order to protect the environment for future generations" [39] (p. 1). Here, the NSPE uses sound language harkening to environmental stewardship, yet the verbiage "encouraged" lacks potency. Nevertheless, if licensed engineers are to employ principles of sustainable development, it seems appropriate for programs to instruct engineering students on these same principles, lest they be expected to pick them up on the job.

\subsubsection{National Council of Examiners for Engineering and Surveying (NCEES)}

In their FE Reference Handbook 10.0.1, the latest resource document that accompanies the mechanical FE exam, environmental topics are shown to appear only in the ethics portion of the exam, without any questions about environmental considerations during the mechanical design process [44]. Thus, programs can position their students to achieve Engineer in Training (EIT) status with virtually no environmental competency. 


\subsubsection{Governmental/Other Influences}

Within the United States, governmental bodies traditionally refrain from imposing degree requirements on engineering programs, especially at the national level. Certain states impose credit hour limits on degrees, usually approximately 120-128 credit hours, which poses a significant challenge to academicians designing engineering curricula, especially as engineering knowledge doubles every decade and environmental topics warrant increased attention. Governmental mandates are more prevalent elsewhere in the world, and other regions also have more variety in the length of time necessary to earn an undergraduate mechanical engineering degree.

As examples, universities in Puerto Rico may require approximately 160 credit hours before graduation in engineering, and the average time to earn a degree in the Philippines is usually lengthened for students from large or poor families, who routinely rotate students in and out of college classes to defer educational costs. Degree requirements are also driven by local industries, so institutions in places like Peru have a greater emphasis on mining and geological topics. Devoutly religious countries, like Saudi Arabia, sometimes also have religious degree requirements. Obviously, these types of regional factors make performing a comprehensive global study impracticable, yet the examples given here can help all researchers appreciate the curricular differences around the world, even when the core technical subject matter is relatively consistent.

\subsection{Mechanical Engineering Programs}

\subsubsection{Core Courses and Environmental Content in Representative Textbooks}

Each school's website enumerates the curricular requirements for earning an undergraduate mechanical engineering degree, allowing the identification of a set of core requirements, after accounting for differences in course titles through the examination of course descriptions. For schools with multiple undergraduate mechanical engineering degrees, such as MIT, the study utilized the standard/traditional track (at MIT termed "Course 2" [45]), leaving specialized emphases to be covered in "3.2.3 Non-Core EnvironmentFocused Mechanical Engineering Courses." Fifteen courses were degree requirements for at least seven of the twelve programs and were considered "core" courses (see left-most column in Table 2). For each course, the identification of a representative textbook occurred via online bookstores and the Open Syllabus Project [20]. For each representative textbook, the amount and nature of the environmental content was categorized based on a four-level ordinal scale: Negligible, Modest, Significant, and Extensive. In short, the environmental content in a textbook is considered: "Negligible" if the amount of coverage is small and the nature is incidental, "Modest" if the environmental content spans more than a few pages and teaches basic environmental care, "Significant" if the environment appears numerous times throughout the text, and "Extensive" if the environment is a central focus of the text, including detailed information and instruction on being an effective steward of the environment.

As shown by the left-most column in Table 2, the mechanical engineering "core" does not currently include any environment-focused courses, and the representative textbook review (shown in the right-most column) reveals that most textbooks used in the top engineering schools barely mention environmental issues, whether in connection to ethics or otherwise. 
Table 2. Core mechanical engineering courses with classification of the environmental content in representative textbooks.

\begin{tabular}{|c|c|c|c|c|}
\hline Representative Course Title & $\begin{array}{l}\text { Number of } \\
\text { Schools }\end{array}$ & Representative Textbook (Year) & Primary Author & $\begin{array}{l}\text { Environmental } \\
\text { Content }\end{array}$ \\
\hline $\begin{array}{l}\text { Introduction to Engineering } \\
\text { (Fundamentals, Profession) }\end{array}$ & 7 & $\begin{array}{c}\text { Engineering Fundamentals: An Introduction to } \\
\text { Engineering, 5th Ed. (2015) [46] }\end{array}$ & Saeed Moaveni & Modest \\
\hline Engineering Graphics (with CAD) & 12 & $\begin{array}{c}\text { Engineering Graphics with Solidworks 2020, } \\
\text { 1st Ed. (2019) [47] }\end{array}$ & David C. Planchard & Negligible \\
\hline $\begin{array}{l}\text { Computer Programming } \\
\text { for Engineers }\end{array}$ & 10 & $\begin{array}{c}\text { MATLAB: A Practical Introduction to } \\
\text { Programming and Problem Solving, 5th Ed. } \\
(2018)[48]\end{array}$ & Stormy Attaway & Negligible \\
\hline Mechanics: Statics ${ }^{+}$ & 8 & $\begin{array}{c}\text { Engineering Mechanics: Statics, 14th Ed. } \\
\text { (2012) [49] }\end{array}$ & Russell C. Hibbeler & Negligible \\
\hline Mechanics: Dynamics & 12 & $\begin{array}{l}\text { Engineering Mechanics: Dynamics, 9th Ed. } \\
\text { (2019) [50] }\end{array}$ & James L. Meriam & Negligible \\
\hline Mechanics of Materials ${ }^{+}$ & 8 & Mechanics of Materials, 10th Ed. (2016) [51] & Russell C. Hibbeler & Negligible \\
\hline $\begin{array}{l}\text { Material Properties and } \\
\text { Processing }{ }^{+}\end{array}$ & 9 & $\begin{array}{l}\text { Materials Science and Engineering, 10th Ed. } \\
\text { (2018) [52] }\end{array}$ & William D. Calllister & Modest \\
\hline System Dynamics and Controls & 10 & $\begin{array}{c}\text { Modeling, Analysis, and Control of Dynamic } \\
\text { Systems, 2nd Ed. (1999) [53] }\end{array}$ & William J. Palm III & Negligible \\
\hline Thermodynamics $^{++}$ & 10 & $\begin{array}{l}\text { Fundamentals of Engineering Thermodynamics, } \\
\text { 8th Ed. (2014) [54] }\end{array}$ & Michael J. Moran & Significant \\
\hline Fluid Mechanics $^{++}$ & 10 & Fluid Mechanics, 8th Ed. (2015) [55] & Frank M. White & Negligible \\
\hline Heat Transfer ${ }^{++}$ & 10 & $\begin{array}{l}\text { Fundamentals of Heat and Mass Transfer, 8th Ed. } \\
\qquad \text { (2018) [56] }\end{array}$ & Theodore L. Bergman & \\
\hline $\begin{array}{l}\text { Electricity and Magnetism (with } \\
\text { Circuits) }\end{array}$ & 8 & Electric Circuits, 11th Ed. (2018) [57] & James W. Nilsson & Negligible \\
\hline Probability and Statistics & 7 & $\begin{array}{l}\text { Statistics for Engineers and Scientists, 5th Ed. } \\
\text { (2019) [58] }\end{array}$ & William C. Navidi & Negligible \\
\hline Machine Design and Analysis ${ }^{++++}$ & 7 & $\begin{array}{c}\text { Shigley's Mechanical Engineering Design, } \\
\text { 10th Ed. (2014) [59] }\end{array}$ & Richard G. Budynas & Negligible \\
\hline Mechanical Design Process & 8 & Mechanical Design Process, 6th Ed. (2017) [60] & David G. Ullman & Negligible \\
\hline
\end{tabular}

+ Excludes overarching courses in "Solid Mechanics". ${ }^{++}$Excludes overarching courses in "Thermal Fluids" and "Thermal Science".

${ }^{+++}$Excludes courses in "Mechatronics". ${ }^{+++}$Courses specifically focused on machine elements often use "Design of Machinery" by Robert

L. Norton [61], which also has negligible environmental content.

\subsubsection{Detailed Survey of Environmental Content in Core Course Textbooks}

When engineering texts attempt to cover environmental topics, coverage typically occurs near the end of the books (i.e., in the last few chapters), presenting superficial information and describing how to help the environment as an individual consumer (instead of the depth necessary to inform engineering practice and develop a sound engineering mindset). A characteristic example of this is Materials Science and Engineering by Callister and Rethwisch [52], where environmental issues are in the last chapter (Chapter 22). Furthermore, it only offers introductory coverage of recycling (despite reworking in the latest edition) and does not detail the basics of material production and disposal.

Of the fifteen textbooks, Fundamentals of Engineering Thermodynamics contains the most environmental content, with "Energy and Environment" boxes throughout and discussions of modern environmental concerns (e.g., battery recycling, renewables, energy storage) [54]. According to the text, thermodynamics is fundamentally concerned with energy and "provides essential concepts and methods for addressing critical twenty-firstcentury issues, such as using fossil fuels more effectively, fostering renewable energy technologies, and developing more fuel-efficient means of transportation. Also critical are the related issues of greenhouse gas emissions and air and water pollution" [54] (p. 2). Still, the first six chapters of the textbook, which would realistically require nearly an entire semester to cover, offer modest coverage; thus, students are unlikely to delve deeply into environmental issues in their "core" thermodynamics course. Continuing with another thermofluids text, Fundamentals of Heat and Mass Transfer, environmental issues rarely garner significant attention, though the authors do briefly address the contribution of $\mathrm{CO}_{2}$ emissions to climate change [56] (p. 41):

As more $\mathrm{CO}_{2}$ is pumped into the atmosphere, mechanisms of radiation heat transfer within the atmosphere are modified, resulting in potential changes in global tempera- 
tures. In a country like the United States, electricity generation and transportation are responsible for nearly $75 \%$ of the total $\mathrm{CO}_{2}$ released into the atmosphere due to energy use.

The last representative text with notable environmental coverage is Engineering Fundamentals: An Introduction to Engineering by Moaveni [46] (p. 54). As an introductory text of nearly 900 pages, the environment receives relatively little coverage, though the text does define the discipline of environmental engineering, contain a subsection of "additional design considerations" in its treatment of engineering design, and commendably motivates the responsibilities of engineers regarding the environment and the need for engineering education to address the environment:

As future engineers, you will be expected to design and provide goods and services that increase the standard of living and advance health care, while also addressing serious environmental and sustainability concerns... when you design products and services, you must consider the link among earth's finite resources, environmental, social, ethical, technical, and economical factors. Moreover, there is an international competition for engineers who can come up with solutions that address energy and food security and simultaneously address the sustainability issues.

The potential shortage of engineers with training in sustainability-engineers who can apply the sustainability concepts, methods, and tools to their problem solving and decision making [sic] processes — could have serious consequences for our future.

While more mathematically focused topics like "Mechanics: Statics" have a weaker connection to the environment, the same is not true for engineering design. Startlingly, Mechanical Engineering Design by Budynas and Nisbett [59] contains negligible environmental content. Terms like "environment", "sustainable", and "green" do not even appear in the index, and none of the chapters or sections are environmentally focused. Furthermore, Mechanical Design Process by Ullman [60] offers very little (a fraction of a page) instruction on considering environmental issues.

\subsubsection{Non-Core Environment-Focused Mechanical Engineering Courses}

Since the mechanical engineering core was assessed collectively among the twelve institutions, individual institutions could still have unique environment-focused degree requirements. Somewhat surprisingly, none of the twelve institutions have any environmentfocused degree requirements! Instead, institutions tend to have environment-focused courses available to fulfill engineering (or technical) electives, sometimes as part of an optional degree concentration. The important distinction with electives, of course, is that students can graduate without taking the courses, with enrollment based on self-selection. Still, exploring these offerings provides an occasion to examine the variety of environmental educational opportunities presently available, and their interrelationships.

MIT, for example, offers a rich selection of environmentally-focused electives, including 2.60[J] Fundamentals of Advanced Energy Conversion (covering "energy conversion and storage" with "emphasis on efficiency, performance, and environmental impact", as well as alternative fuels and " $\mathrm{CO}_{2}$ separation and capture"), 2.650[J] Introduction to Sustainable Energy (focusing on "meeting 21st-century regional and global energy needs in a sustainable manner"), and 2.813 Energy, Materials, and Manufacturing (which "addresses industrial ecology, material flows, life-cycle analysis, ... design for the environment, recycling and ecological economics"). Interested students are also offered the opportunity to earn an Environment and Sustainability minor through the institution's Environmental Solutions Initiative (ESI), through courses like 2.00C/1.016[J] Design for Complex Environmental Issues: Building Solutions and Communicating Ideas [62].

Georgia Tech offers similar environmentally focused courses, including ME 4171 Environmentally Conscious Design and Manufacturing, ME 4172 Designing Sustainable Engineering Systems, and ME 6759 Materials in Environmentally Conscious Design and Manufacturing [63]. Additionally, students are offered courses in Wind Engineering (ME 
4701), Bio-Inspired Design (ME 4740), and Introduction to Energy Systems Engineering (ME 3700). Georgia Tech has several optional concentrations, without any being specifically environment focused. Stanford, by comparison, requires students to choose a concentration, yet none of the concentrations center on the environment, although students may choose to join their Engineers for a Sustainable world student group [64].

Michigan offers a slightly broader elective option titled ME 489 Sustainable Engineering and Design [65], described as:

ME 489 covers economic, environmental and social aspects of sustainability as they per-
tain to engineering design. The course covers life cycle assessment, carbon/water/energy
footprints, economic assessments, mass/energy balances, air/water pollutants, modeling
of environmental pollutant concentrations, engineering economics, social considerations,
pollution prevention, resource conservation, human and eco-toxicity, life cycle costing,
and energy systems.

Despite having a design focus, the course covers a broad variety of environmental considerations, and while the focus is mainly analytical, it is not structured as a "design to solve a problem" course. Thus, students learn empirical ways to measure environmental impact in a format that will likely help them to be mindful of the importance of caring for the environment.

UC Berkeley's technical electives predominantly follow traditional subject areas, such as MECENG 146 Energy Conversion Principles, although a minority of electives can be taken from a longer list extending outside ME-sponsored courses, most importantly including civil engineering courses. Students could choose to take courses like CIV ENG 107 Climate Change Mitigation, covering greenhouse gases and "options for responding to climate change", as well as CIV ENG C106 Air Pollution, CIV ENG 108 Air Pollutant Emissions and Control, and CIV ENG 113N Ecological Engineering for Water Quality Improvement [66]. Caltech's curriculum allows numerous electives, of which the primary option is ME 117 Energy Technology and Policy, allowing sufficient time to explore the complexities of the energy sector, and to become familiar with "new and emerging technologies" [67].

Purdue's mechanical engineering program requires nine credit hours of mechanical engineering electives and nine credit hours of technical electives [68]. Of the many courses available to fulfill technical electives, only a small portion have an environmental emphasis. To satisfy mechanical engineering electives, students have three main eco-focused options (out of over 50 courses), ME 440 Automotive Prime Movers: Green Engines and Clean Fuel, ME 514 Fundamentals of Wind Energy, and ME 522 Indoor Environmental Analysis and Design. Illinois has a similar elective structure (requiring six credits of mechanical and six credits of technical electives), and lengthy list of technical elective courses, yet without any eco-focused ME elective options [69,70].

Carnegie Mellon offers an exceptional collection of eco-focused mechanical engineering technical electives, including lower-division courses 24-292 Renewable Energy Engineering and 24-291 Special Topics: Environmental Systems on a Changing Planet, and upper-division courses 24-424 Energy and the Environment, 24-425 Combustion and Air Pollution Control, and 24-683 Design for Manufacture and the Environment [71]. Students may be motivated to take several of these courses in pursuit of Carnegie Mellon's minor in Environmental and Sustainability Studies [72].

University of Texas students fulfill 12 credit hours of Career Gateway Electives, within which they select at least one track. For example, the most relevant track is Energy Systems Engineering, wherein students choose three of eleven elective courses, with options including ME 374T Renewable Energy Technology, ME 378E Nanotechnology for Sustainable Energy, and ME 379M Development of Solar-Powered Vehicle [73]. These courses are also options in the Humanitarian Engineering track [74].

Benedictine College has an elective structure with Primary and Secondary ME Electives [75]. Within the list of primary electives is MENG-4860 Intermediate Thermodynamics, for which the course description states "... The course also focuses on environmental 
impact, including emissions and refrigerant properties." [75] (p. 275). Secondary electives also offer a single option, CIVL-4310 Environmental Engineering I [75] (p. 275). These comprise a relatively small selection; however, the School of Engineering also offered a special topics course titled Environmental Stewardship. The course employed a great books format to holistically approach the role of the engineer as a steward of the earth, aiming to convey the importance of the environment to every engineer. Subsequently, due to the importance of the topic and student requests to regularly offer the course, MENG-4830 Environmental Stewardship became a regular catalog course fulfilling a primary elective.

The Catholic University of America offers two curricular programs (sets of courses) with an environmental focus. Students can earn an Honors in Environmental Studies by taking the four courses in The Environment, Energy, and Policy and a Sustainability minor [76], and an Energy and the Environment concentration [77]. Course wise, the institution offers ME 426 Alternative Energy Engineering, ME 427 Renewable Energy and Technology, ME 428 Energy Storage: Technology and Design, ME 437 Air Pollution and Control, ME 438 Design of Solar Systems and Wind Power, and ME 512 Energy Materials I-Supercapacitors and Batteries [78].

\subsection{Holistic Analysis of ME Program Environmental Content}

As the present survey indicates, mechanical engineering programs have relatively soft/minor external influences driving environmental education. Programs tend to leave eco-education predominantly to student self-selection through a diverse collection of environment-focused elective courses, with sparse coverage in core course textbooks and no environment-focused degree requirements. As such, programs tend to lack the systematic, coordinated instruction students need to graduate prepared to be responsible stewards of the environment.

Tying back to the original research question, the survey shows most textbooks employed in US undergraduate mechanical engineering curricula have negligible environmental content, with a few having modest coverage, typically tied to the context of the course (e.g., material recyclability, renewable energy). Therefore, the amount of environmental education guaranteed to mechanical engineering students as an essential part of their education likely equates to a paltry handful of class periods (depending on the instructors). Additionally, the core course environmental education is unlikely to motivate students to take environment-focused electives, so their level of "caring" may even fall below their "knowing". Many curricula require approximately five electives and have approximately $10 \%$ of electives being environment-focused, meaning about half of students who select electives non-preferentially across areas of mechanical engineering would take zero environment-focused electives and about half would take one. Fortunately, students who care about environmental issues have multiple options available, but unfortunately students without environmental proclivities will likely take courses in more familiar and interesting (to them) areas.

The curriculum study also shows the type of sustainability education students receive to be overly technical in nature, with very few courses designed to broadly educate students on the value of the environment and the interconnectedness of nature (e.g., ME 4172 Designing Sustainable Engineering Systems at Georgia Tech, ME 489 Sustainable Engineering and Design at Michigan, MENG-4830 Environmental Stewardship at BC), instead focusing on the design and analysis of green technologies (e.g., Wind Energy, Alternative Fuels for Engines). Several institutions do have environment-themed non-major academic programs (e.g., academic minors, tracks, or emphases), including MIT, Carnegie Mellon, Texas, and CUA.

\section{Discussion}

As mentioned in Section 1.1, the preceding survey illustrates the environmental education occurring in US undergraduate ME programs. Through the discussion here, further implications of the status quo are explored pedagogically and societally, and Section 5 (Con- 
clusions) offers a preliminary proposal for a new "environmental stewardship" curriculum. Since the survey was designed to examine what sustainability education is occurring, it merely initiates a discussion of what sustainability education should be occurring. Reasoning out new proposals requires answering underlying questions about the proper nature of environmental education, its suitability for current students, and its relationship to external organizations and existing curricula. A few characteristics of sound environmental education are fleshed out below:

Environmental education should be less technical. The social behaviorist approach focuses on the evaluation of current technical designs and solutions, whereas the experientialist approach emphasizes caring for the environment. Arguably the latter is more important and almost completely ignored by most curricula. For example, with respect to ABET and its 2019-2020 student outcome revisions, eco-focused courses tend to be technical/design-focused (corresponding to outcome (2)) rather than stewardship/impactfocused (corresponding to outcome (4)). The environment is the ultimate "big picture" topic, which explains why compartmentalized analysis inadequately prepares students to understand the interconnected web of nature. It does not appear as though enough courses are designed to develop engineers who are informed stewards of the environment; every undergraduate ME program should offer a course with broad coverage of environmental issues.

Environmental education should be shown to be essential. Too many textbooks offer superficial coverage beside the main text or at the "end of the story", implicitly situating the environment as a peripheral issue. Academicians should recognize the fine line between systematically covering the environment throughout the curriculum and consistently mentioning the environment in a superfluous manner. To accomplish this, instructors will have to develop supplementary course materials to counteract the deficiencies of current textbooks and properly convey the importance of environmental topics. Through dedicated courses, research projects, or design projects, instructors should avoid the unfitting approach of always covering the environment in small segments, instead dedicating an entire course, a major portion of a course, or a major portion of multiple courses to the environment.

Environmental education should be updated for the "Gen $Z$ " engineering student population. Green design principles (e.g., reducing superfluous material, designing for recyclability, avoiding toxic materials, using replaceable components) are valid across cultures, though today's undergraduates differ in important ways from previous generations. As the first generation to grow up with portable digital electronics, Gen Zers are increasingly isolated from the natural world, suggesting that curricula should incorporate connectivism, sending students out to appreciate the grandeur of the natural world. For many, nature is an abstract concept that will not be appreciated until it is "encountered". As a generation susceptible to psychological distress, connectivistic environmental experiences may be therapeutic. By nurturing and healing the environment, we nurture and heal ourselves. Like millennials, Gen Z students are motivated by contributing to a greater cause, and can find meaning in environmentally-beneficial educational projects. Additionally, with shortened attention spans and habitual "googling" for answers, incoming engineering students have diminished aptitudes for looking multi-dimensionally at environmental impacts (as opposed to performing calculations). Consequently, students need instruction on how to approach the environment as one large, complex system to be cared for, not something to be harnessed or solved.

Environmental education should exceed the requirements of external organizations and encourage the adoption of stronger language. ABET's elimination of the phrase "broad education" in connection with the environment further enables the attainment of outcome (2) through the inclusion of token capstone design constraints "considering" environmental "factors". In general, external organizations tend to use language (especially prepositions) that are soft and relative rather than firm and objective. To exert positive influences on curricula, organizations should embrace outcome-based statements like 
"conserving and protecting" [39] instead of "considering" [36]. Additionally, the rationale for environmental care should be rooted in the inherent value of the environment rather than "sustainability" or "future development" [39].

Environmental education should rely on scientific and ethical foundations. Students who take Newtonian physics know the science behind the forces and motion found in Mechanics (Statics and Dynamics), and graduates of general chemistry understand the atomic phenomena driving Materials Science, yet few institutions have students learn the science behind climate change (e.g., by reading [1]). A similar deficiency exists with ethics, with a minority of institutions requiring courses in ethics, instead relying on course modules covering the codes of ethics of organizations like the ASME and NSPE, which are by nature guidelines instead of foundational ethical principles. ABETs outcome (4) evokes simplistic professional ethics case studies promoting "informed judgements" that "consider the impact of engineering solutions in ... environmental ... contexts". Thus, curricula should educate students on the fundamental ethical principles underlying professional codes (e.g., by reading [79]) and include detailed study of complex, challenging ethical dilemmas.

Environmental education can occur while fulfilling other curricular needs. When developing the BC Environmental Stewardship course, it was apparent that the mechanical engineering program already had a strong collection of educational laboratories, design courses, and project-based learning, so the course was structured to include readings and discussions of prominent ethics texts, seminal scientific data and publications, and government regulations and policies. Experientially, the course required solitary excursions into nature, eventually accompanied by a detailed personal reflection on the student's relationship with the environment. After forming students as informed stewards of the environment, the course shifted to a guided research format, allowing students to explore contemporary environmental issues and perform novel research as undergraduates. Guided research appears to be an apt antidote to the superficial environmental content that pervades baccalaureate ME programs.

\section{Conclusions}

A new curriculum proposed here shall be called the "environmental stewardship" curriculum. Its objective is to ground and inform students, relying both on scientific and non-technical lessons to foster a deep understanding and appreciation for the environment. It is intimated that programs retain many of the existing elective courses on green technologies, while imbuing them with environmental humanities. By doing so, students will develop multi-dimensional thinking and appreciate the complexities of designing and proliferating new technologies. Existing fundamental "core" engineering courses can also be modified instead of redesigned, but those modifications will require educators to work collaboratively to achieve cohesiveness in a type of "systematically greening the curriculum" initiative. Educating engineers on the environment has to occur throughout curricula, since widespread coverage conveys the broad relevance of the environment.

The cornerstone of the "environmental stewardship" curriculum is the adoption of an environment-centered degree requirement. Students take materials science, why? Because they will inevitably work with materials. This is precisely why an environmentfocused course is necessary; students will inevitably work with the environment. Students do not choose whether they learn about materials, and the same logic follows for the environment. Materials, of course, enjoy a traditional position in degree programs, and additional credit hours are often difficult to have approved. So, although it breaks with the ASME Strategy Vision 2030s call for increased program flexibility [80], the most practicable option appears to be replacing one elective course with a new fundamental engineering course on the environment.

Within this fundamental environment course, students can realize the benefits of the intellectual traditionalist approach in the environmental context, looking to the great books, liberal arts, and religious traditions for innovative strategies to advance sustainability. 
Instead of being presented with broadly synthesized information, students can read seminal works like the scientific reports of the IPCC [81], the regulatory policies of the US EPA [82], and ethical viewpoints of religious figures like Pope Francis [2]. Furthermore, great books include works like Desert Solitaire [83] and Silent Spring [84], which are just as relevant to the intellectual formation of engineers as sizing a photovoltaic array or a battery storage power station. Information alone is not sufficient to help students appreciate the grandeur of nature, and classroom activities will not genuinely connect our industrialized, urbanized students to the natural world, so educators may need to take the drastic step of sending their students "into the wild".

Author Contributions: The authors collaboratively conceptualized the research effort and worked together on the investigation and methodology. Initially drafted the introduction and methods, A.D.; initially drafted core course results, M.D.; initially drafted the non-core course results, G.R.; analyzed external influences, provided global context, drafted the discussion, and provided resources, administration, review, editing, and revisions, C.E.S.III. All authors have read and agreed to the published version of the manuscript.

Funding: This research received no external funding.

Institutional Review Board Statement: Not applicable.

Informed Consent Statement: Not applicable.

Data Availability Statement: There are no publicly archived datasets.

Acknowledgments: The authors wish to thank the Benedictine College Honor's Program for sponsoring the MENG-4980 Environmental Stewardship special topics course.

Conflicts of Interest: The authors declare no conflict of interest.

\section{References}

1. Woodhouse, E. Overconsumption and Engineering Education: Confronting Endless Variety and Unlimited Quantity. Int. J. Eng. Educ. 2003, 19, 124-131.

2. Pope Francis, I. Laudato Si': On Care for Our Common Home; Libreria Editrice Vaticana: Vatican City, 2015.

3. Newnan, D.; Eschenbach, T.; Lavelle, J.; Lewis, N. Engineering Economic Analysis, 14th ed.; Oxford University Press: New York, NY, USA, 2019.

4. Glavič, P. Sustainability engineering education. Clean Technol. Environ. Policy 2006, 8, 24-30. [CrossRef]

5. US News \& World Report. 2021 Best Undergraduate Mechanical Engineering Programs. 2020. Available online: https: //www.usnews.com/best-colleges/rankings/engineering-doctorate-mechanical (accessed on 17 December 2020).

6. Morse, R.; Vega-Rodriguez, J.; Castonguay, A.; Brooks, E. Methodology: 2021 Best Engineering Schools Rankings. U.S. News \& World Report. 16 March 2020. Available online: https://www.usnews.com/education/best-graduate-schools/articles/ engineering-schools-methodology (accessed on 17 December 2020).

7. The Cardinal Newman Society. Recommended Colleges for Catholic Families. 2021. Available online: https:/ / newmansociety. org/college/ (accessed on 27 January 2021).

8. MIT. Department of Mechanical Engineering-Subjects. 2020. Available online: http://catalog.mit.edu/schools/engineering/ mechanical-engineering/\#subjectstext (accessed on 17 December 2020).

9. Georgia Tech. Undergraduate Program. 2020. Available online: http://www.me.gatech.edu/undergraduate (accessed on 22 December 2020).

10. Stanford. 2020-21 Mechanical Engineering UG Major; Stanford University: Stanford, CA, USA, 2020.

11. Michigan. Mechanical Engineering. 2020. Available online: https://me.engin.umich.edu/ (accessed on 17 December 2020).

12. UC Berkeley. Mechanical Engineering. 2020. Available online: https://engineering.berkeley.edu/students/undergraduateguide/degree-requirements/major-programs/me/ (accessed on 17 December 2020).

13. Caltech. Course Schedule. 2020. Available online: https://www.mce.caltech.edu/academics/course_schedule (accessed on 17 December 2020).

14. Purdue. Undergraduate. 2020. Available online: https://engineering.purdue.edu/ME/Undergraduate (accessed on 22 December 2020).

15. Illinois. Undergraduate Programs. 2020. Available online: https://mechse.illinois.edu/undergraduate (accessed on 22 December 2020).

16. Carnegie Mellon. Undergraduate Program. 2020. Available online: https://www.meche.engineering.cmu.edu/education/ undergraduate-education/index.html (accessed on 17 December 2020). 
17. Texas. Undergraduate Program. 2020. Available online: https://www.me.utexas.edu/academics/undergraduate-program (accessed on 22 December 2020).

18. Benedictine College. Mechanical Engineering. 2020. Available online: https://www.benedictine.edu/academics/degrees/ mechanical-engineering/index (accessed on 22 December 2020).

19. CUA. 2020. Available online: https://engineering.catholic.edu/academics/undergraduate/mechanical-engineering/index.html (accessed on 22 December 2020).

20. Open Syllabus Explorer. Mapping the College Curriculum across 6,059,459 Syllabi. 2021. Available online: https: / opensyllabus. org/ (accessed on 17 December 2020).

21. Splitt, F.G. Environmentally Smart Engineering Education: A Brief on a Paradigm in Progress. J. Eng. Educ. 2002, 91, 447-450. [CrossRef]

22. Shuman, L.J.; Besterfield-Sacre, M.; McGourty, J. The ABET “Professional Skills"—Can They Be Taught? Can They Be Assessed? J. Eng. Educ. 2005, 94, 41-55. [CrossRef]

23. Bucciarelli, L.L.; Coyle, E.; McGrath, D. Chapter 5: Engineering Education in the US and the EU. In Engineering in Context; Academica: Aarhus, Denmark, 2009; pp. 105-128.

24. Wareham, D.G.; Elefsiniotis, P. Environmental Ethics in Engineering Education: A Missing Fundamental. Water Sci. Tech. 1996, 34, 197-203. [CrossRef]

25. Hyde, R.A.; Karney, B.W.; Kennedy, C.A. Fishing for a New Way to Teach Environmentally Sensitive Engineering Practice. Bull. Sci. Technol. Soc. 2000, 20, 383-392. [CrossRef]

26. Hyde, R.A.; Karney, B.W. Environmental Education Research: Implications for Engineering Education. J. Eng. Educ. 2001, 90, 267-275. [CrossRef]

27. Lathem, S.A.; Neumann, M.D.; Hayden, N. The Socially Responsible Engineer: Assessing Student Attitudes of Roles and Responsibilities. J. Eng. Educ. 2011, 100, 444-474. [CrossRef]

28. Roeser, S. Emotional Engineers: Toward Morally Responsible Design. Sci. Eng. Ethics 2012, 18, 103-115. [CrossRef] [PubMed]

29. Guerra, A. Integration of Sustainability in Engineering Education: Why is PBL an answer? Int. J. Sustain. High. Educ. 2017, 18, 436-454. [CrossRef]

30. Sanganyado, E.; Nkomo, S. Incorporating Sustainability into Engineering and Chemical Education Using E-Learning. Educ. Sci. 2018, 8, 39. [CrossRef]

31. Ramanujan, D.; Zhou, N.; Ramani, K. Integrating environmental sustainability in undergraduate mechanical engineering courses using guided discovery instruction. J. Clean. Prod. 2018, 207, 190-203. [CrossRef]

32. Segalàs, J.; Ferrer-Balas, D.; Mulder, K.F. Conceptual maps: Measuring learning processes of engineering students concerning sustainable development. Eur. J. Eng. Educ. 2008, 33, 297-306. [CrossRef]

33. Lau, A. Sustainable Design: A New Paradigm for Engineering Education. Int. J. Eng. Educ. 2010, 26, 252-259.

34. Weber, N.R.; Strobel, J.; Dyehouse, M.A.; Harris, C.; David, R.; Fang, J.; Hua, I. First-Year Students' Environmental Awareness and Understanding of Environmental Sustainability through a Life Cycle Assessment Module. J. Eng. Educ. 2014, 103, 154-181. [CrossRef]

35. Glavič, P.; Lukman, R. Review of sustainability terms and their definitions. J. Clean. Prod. 2007, 15, 1875-1885. [CrossRef]

36. ABET. Criteria for Accrediting Engineering Programs (During the 2020-2021 Accreditation Cycle); ABET: Baltimore, MD, USA, 2019.

37. ABET. ABET Member Societies. 2021. Available online: https://www.abet.org/member-societies/ (accessed on 21 August 2020).

38. ASME. Code of Ethics of Engineers; American Society of Mechanical Engineers: New York, NY, USA, 2012.

39. NSPE. Code of Ethics for Engineers; National Society of Professional Engineers: Alexandria, VA, USA, 2019.

40. ABET. Why ABET Accreditation Matters. 2021. Available online: https://www.abet.org/accreditation/what-is-accreditation/ why-abet-accreditation-matters / (accessed on 24 August 2020).

41. ABET. Criteria for Accrediting Engineering Programs (During 2018-2019 Accreditation Cycle); Accreditation Board of Engineering and Technology, Inc.: Baltimore, MD, USA, 2017.

42. ABET. Criteria for Accrediting Engineering Programs (During 2019-2020 Accreditation Cycle); ABET: Baltimore, MD, USA, 2018.

43. ASME. The ASME Criteria for Interpretation of the Canons; American Society of Mechanical Engineers: New York, NY, USA, 2012.

44. NCEES. FE Reference Handbook 10.0.1; National Council of Examiners for Engineering and Surveying (NCEES): Greenville, SC, USA, 2020.

45. MIT. Degree Charts: Mechanical Engineering (Course 2). 2020. Available online: http://catalog.mit.edu/degree-charts/ mechanical-engineering-course-2/ (accessed on 8 January 2021).

46. Moaveni, S. Engineering Fundamentals: An Introduction to Engineering, 5th ed.; Cengage Learning: Boston, MA, USA, 2015.

47. Planchard, D.C. Engineering Graphics with SOLIDWORKS 2020; SDC Publications: Mission, KS, USA, 2019.

48. Attaway, S. MATLAB: A Practical Introduction to Programming and Problem Solving, 5th ed.; Butterworth-Heinemann: Waltham, MA, USA, 2018.

49. Hibbeler, R.C. Engineering Mechanics: Statics; Pearson: London, UK, 2015.

50. Meriam, J.L. Engineering Mechanics: Dynamics, 9th ed.; John Wiley \& Sons: Hoboken, NJ, USA, 2019.

51. Hibbeler, R.C. Mechanics of Materials, 10th ed.; Pearson: London, UK, 2016.

52. Callister, W.D.; Rethwisch, D.G. Materials Science and Engineering, 10th ed.; John Wiley \& Sons: Hoboken, NJ, USA, 2018.

53. Palm, W.J., III. Modeling, Analysis, and Control of Dynamic Systems, 2nd ed.; John Wiley \& Sons: Hoboken, NJ, USA, 1999. 
54. Moran, M.J.; Shapiro, H.N.; Boettner, D.D.; Bailey, M.B. Fundamentals of Engineering Thermodynamics, 8th ed.; John Wiley \& Sons: Hoboken, NJ, USA, 2015.

55. White, F.M. Fluid Mechanics, 8th ed.; McGraw-Hill Education: New York, NY, USA, 2015.

56. Bergman, T.L.; Lavine, A.S.; Incropera, F.P.; Dewitt, D.P. Fundamentals of Heat and Mass Transfer, 8th ed.; John Wiley \& Sons: Hoboken, NJ, USA, 2018.

57. Nilsson, J.W.; Riedel, S.A. Electric Circuits, 11th ed.; Pearson: London, UK, 2018.

58. Navidi, W. Statistics for Engineers and Scientists, 5th ed.; McGraw-Hill Education: New York, NY, USA, 2019.

59. Budynas, R.G.; Nisbett, J.K. Shigley's Mechanical Engineering Design, 10th ed.; McGraw-Hill Education: New York, NY, USA, 2014.

60. Ullman, D.G. Mechanical Design Process; David Ullman LLC: OR, USA, 2017; Available online: https://www.mechdesignprocess. $\mathrm{com} /$ mechanical-design-process-text (accessed on 20 June 2021).

61. Norton, R.L. Design of Machinery, 6th ed.; McGraw-Hill Education: New York, NY, USA, 2019.

62. MIT-ESI. Environmental Solutions Initiative: Environment \& Sustainability Minor. 2020. Available online: https: / / environmentalsolutions.mit.edu/classes-search/?_sfm_courses=course2 (accessed on 12 January 2021).

63. Georgia Tech. 2020-2021 Course Catalog. 2020. Available online: https://catalog.gatech.edu/coursesaz/me/ (accessed on 12 January 2021).

64. Stanford-ME Student Organizations. Engineers for a Sustainable World. 2021. Available online: https://me.stanford.edu/ourculture/student-organizations (accessed on 12 January 2021).

65. Michigan. ME 489 Course Profile. 2021. Available online: https://deptapps.engin.umich.edu/courses/abet/profile/printview? num $=489$ (accessed on 12 January 2021).

66. UC Berkeley. Mechanical Engineering Undergraduate Technical Electives. 2020. Available online: https://me.berkeley.edu/ undergraduate/technical-electives/ (accessed on 12 January 2021).

67. Caltech. Course Descriptions. 2020. Available online: https://www.mce.caltech.edu/academics/course_desc (accessed on 12 January 2021).

68. Purdue. Mechanical Engineering Electives \& Technical Electives in the Mechanical Engineering Curriculum. 2020. Available online: https: / engineering.purdue.edu/ME/Undergraduate/METechElects.html (accessed on 12 January 2021).

69. Illinois. BS in Mechanical Engineering_Program Overview. 2020. Available online: https://mechse.illinois.edu/undergraduate/ bs-mechanical-engineering\#CurriculumReq (accessed on 12 January 2021).

70. Illinois. Undergraduate Course Offerings; Mechanical Science \& Engineering: Champaign, IL, USA, 2021.

71. Carnegie Mellon. Mechanical Engineering Technical Electives. 2021. Available online: http://coursecatalog.web.cmu.edu/ schools-colleges/collegeofengineering/departmentofmechanicalengineering/\#electivesandrestrictedelectivestext (accessed on 13 January 2021).

72. Carnegie Mellon. Course Descriptions. 2020. Available online: http://coursecatalog.web.cmu.edu/schools-colleges/ collegeofengineering/departmentofmechanicalengineering/\#coursestextcontainer (accessed on 13 January 2021).

73. Texas-Energy Systems. Energy Systems Engineering. 2020. Available online: https://www.me.utexas.edu/images/cge/ EnergySystems.pdf (accessed on 13 January 2021).

74. Texas-Humanitarian Engineering. Humanitarian Engineering. 2020. Available online: https://www.me.utexas.edu/images/ cge/HumanitarianEngineering2020.pdf (accessed on 13 January 2021).

75. Benedictine College. Benedictine College Course Catalog 2020-2021. 2020. Available online: https://www.benedictine.edu/ academics/catalog/index (accessed on 13 January 2021).

76. CUA. 2020-2021 Announcements: Undergraduate Studies. 2020. Available online: https://docs.google.com/document/d/11 gcrZLaoLIcLNclj2ZIs370v3uLUXFagRscm9wMT3Og/edit (accessed on 13 January 2021).

77. CUA-Explore Topics. Explore Topics. 2020. Available online: https://engineering.catholic.edu/academics/departments/ explore-topics.html (accessed on 13 January 2021).

78. CUA. Course Offered in Mechanical Engineering. 2021. Available online: https://engineering.catholic.edu/mechanical/coursesoffered/index.html (accessed on 13 January 2021).

79. Seebauer, E.G.; Barry, R.L. Fundamentals of Ethics for Scientists and Engineers, 1st ed.; Oxford University Press: New York, NY, USA, 2001.

80. ASME. Strategy Vision 2030. 2008. Available online: https://www.asme.org/asme-programs/students-and-faculty/engineeringeducation/strategy-vision-2030 (accessed on 8 June 2021).

81. IPCC. Global Warming of 1.5 Degrees Celsius; IPCC: Geneva, Switzerland, 2019.

82. US EPA. Regulatory Information by Topic. 2021. Available online: https:/ /www.epa.gov/regulatory-information-topic (accessed on 8 June 2021).

83. Abbey, E. Desert Solitaire: A Season in the Wilderness; Ballantine Books: New York, NY, USA, 1968.

84. Carson, R. Silent Spring; Houghton Mifflin Company: Boston, MA, USA, 1962. 